Hodgkin's Disease of the Thymus

Sir David Smithers, F.R.c.P. .........

Hepatic Sensitization to Halothane

M. W. Johnstone, M.D. ............

Neutropenia after Trimethoprim/

Sulphamethoxazole for Bronchitis

Amoebic Dysentery Precipitated by

S. R. Kanani, M.B., and R. Knight,

S. R. Kanani, M.B., and R. Knight,

D.T.M.\&H. $\quad$.....

Hospital Planning

F.R.C.S. ..................114

Local Use of Progestogen in Cancer

I. L. Craft, F.R.C.S. ......................115
Oral Contraceptives and Thromboembolic Disease

C. D. Needham, F.R.C.P. ................115

Payment by Colour

C. Gazidis, M.B. .......................115

Diseases of Joints

J. H. Cyriax, M.D. .......................116

Treating Shock

N. McE. Lamont, F.R.C.P.GLASG., and K.

Posel, D.sc. ..................................116

Anticoagulants after Myocardial Infarction

W. G. Walker, jun., M.D. .................116

Intermittent Methohexitone

G. G. P. Holden, L.D.s. R.c.s.
Vitamin $A$ and the Skin

P. A. Riley, M.B.

Metabolism in Parkinsonian Patients

F. Carswell, M.R.C.P., and I. W. Dymock,

M.R.C.P.ED. '..............................118

Prevention of Prolonged Labour

C. J. B. Orr, F.A.C.S. .....................118

Abortion Act in Practice

G. J. Davies, M.B.

Treatment of the Phobic Anxiety State

W. W. Sargant, F.R.C.P. .................118

Potassium Supplementation

J. E. Yarborough, F.P.s.

\section{Hodgkin's Disease of the Thymus}

SIR,-Your leading article (21 June, p. 713) deals with some of the interesting associations between the thymus and Hodgkin's disease. It is probable that granulomatous thymoma (as Ackerman ${ }^{1}$ maintained) is indeed part of Hodgkin's disease, but definition is difficult, as pathologists mus find Sternberg-Reed cells before they make their diagnosis. So far, while accepting the probability, we have kept granulomatous thymomas without demonstrable SternbergReed cells in a separate category. To discuss this problem, as your leading article does, without reference to the work of Ackerman or Lowenhaupt ${ }^{2}$ is unusual.

Hodgkin's disease is primarily a disorder of lymph nodes spreading predominantly to other nodes. It may arise in a number of extranodal sites, one of which is the thymus. However, even if all granulomatous thymomas are included with those showing obvious Hodgkin's disease of the thymus, such an origin is still rare. I challenged A. D. Thomson's ${ }^{4}$ theory that Hodgkin's disease was a primary carcinoma of the thymus at the time it was put forward, ${ }^{5}$ while stressing the many associations between the thymus and the lymphomas. More evidence has come to light since then, particularly through their common relationships with immune disorder. As your leading article says, granulomatous thymoma is not known to be associated with myasthenia gravis, but we have recently reported $^{6}$ a case of Hodgkin's disease of the thymus which was associated with a pure red cell aplasia.

It may be that secondary involvement of the thymus is even less common than primary, thymus.

London S.W.3. 2, 263 and 337 . Press. though this is another distinction not easily made. In my experience ${ }^{7}$ thymic Hodgkin's disease has a rather good prognosis favouring localized involvement. I have suggested ${ }^{8}$ that a possible explanation of the infrequency of secondary involvement of the thymus in Hodgkin's disease may be due to the fact that recirculating lymphoid cells "home" to the lymph nodes and spleen but not to the

We require a critical review of the diagnosis of Hodgkin's disease as made by pathologists with reference to its possible recognition without the confirming presence of SternbergReed cells, which might provide a more secure classification for granulomatous thymoma. We are further in need not only of a better account of those immune defects which may arise in the course of Hodgkin's disease but of those which may be concerned in its initiation.-I am, etc.

Royal Marsden Hospital

D. W. SMithers.

\section{REFERENCES}

Ackerman, L. V., Surgical Pathology, 1959, 2nd ed., p. 239. St. Louis, Mosby.
Lowenhaupt, E., and Brown, R., Cancer, 1951, 4, Lowenhaupt, E., and Brown, R., Cancer, 1951, 4,
1193 .

9, 37. A. D., British fournal of Cancer, 1955, Thomson, A. D., Proceedings
of Medicine, 1956, 49, 97 .

Smithers, D. W., Proceedings of the Royal Society of Medicine, 1956, 49, 103

Field, E. O., Caughi, M. N., Blackett, N. M. and Smithers, D. W. British fournal of Hacmatology, $1968,15,101$.
mithers, D. W., British Medical fournat, 1967,

Smithers, D. W., The Scientific Basis of Medicine Annual Reviews, 1969, 6, 96. London, Athlone

\section{Hepatic Sensitization to Halothane}

SIR,-Your leading article (21 June, p. 714) suggests that the jaundice which may follow halothane anaesthesia may be due to the sensitization of the liver to halothane.
The suggestion would be more convincing if it were supported by more direct evidence of the assumed antigenicity of halothane. Allergic liver necrosis is readily reproducible in animals sensitized to a specific antigen.

It is interesting to note that the incidence of the post-anaesthetic jaundice-1 in 10,000 administrations-is exactly similar to the predicted incidence of coincidental viral hepatitis in surgical patients one or more weeks after anaesthesia. ${ }^{2}$ It has recently been observed in rats that halothane reduces the number of antibody-producing splenic lymphocytes. ${ }^{3}$ There is therefore the possibility that halothane may upset the antigen-antibody ratio in patients with latent or chronic viral hepatitis, thereby precipitating an acute attack of the disease.

It is obvious that the problem of unexplained post-anaesthetic jaundice will not be solved until physicians provide themselves with the ability to diagnose viral hepatitis with serological and virological accuracy. -I am, etc.,

Michael Johnstone. Royal Infirmary.
Manchester.

REFERENCES

Sabesin, S. M., American fournal of Pathology, $1963,42,743$.

2 Bunker, J. P., and Blumenfeld, C. M., New England fournal of Medicine, $1963,268,531$. Wingard, D. W., and Humphrey, L. J., Anesthesiology, 1969, 30, 353.

\section{Neutropenia after Trimethoprim/ \\ Sulphamethoxazole for Bronchitis}

SIR,-It has been shown that there is strong synergy between trimethoprim with a sulphonamide and that the combined action is bacterioidal. ${ }^{1}$ Recently there have been several favourable reports on its use in chronic bronchitis ${ }^{2}$ and urinary tract infections $^{34}$ without major adverse effects. Thirtytwo of our patients with acute or chronic bronchitis were given 36 courses of trimethoprim sulphamethoxazole. In four patients significant neutropenia occurred, without clinical illness,

Their treatment regimen was either trimethoprim $320 \mathrm{mg}$. with sulphamethoxazole 


\begin{tabular}{|c|c|c|c|c|c|c|c|c|c|c|}
\hline No. & Age & Sex & Diagnosis & Dosage & $\begin{array}{l}\text { Length of } \\
\text { treatment }\end{array}$ & \multicolumn{5}{|c|}{ Day of white cell count in brackets } \\
\hline 1 & 64 & $M$ & C.B. & 3 b.d. & 14 days & $\begin{array}{c}(1) \\
\text { WBC } 5100 \\
\text { N } 3400\end{array}$ & $\begin{array}{l}(14) \\
3500 \\
2000\end{array}$ & & & \\
\hline 2 & 17 & $M$ & B & 3 b.d. & 14 days & $\begin{array}{l}\text { (1) } \\
\text { WBC } 4800 \\
\mathrm{~N} \quad 2800\end{array}$ & $\begin{array}{l}(14) \\
3800 \\
2400\end{array}$ & $\begin{array}{r}(28) \\
4500 \\
2000\end{array}$ & . & \\
\hline 3 & 44 & $M$ & $\begin{array}{l}\text { C.B } \\
\text { A }\end{array}$ & 3 b.d. & 7 days & $\begin{array}{l}\text { (1) } \\
\text { WBC } 5000 \\
\text { N "normal" }\end{array}$ & $\begin{array}{l}(7) \\
3000 \\
1100\end{array}$ & & & \\
\hline 4 & 73 & F & C.B. & 2 b.d. & 7 days & $\begin{array}{ll} & (1) \\
\text { WBCC } & 5600 \\
\mathrm{~N} & 3700\end{array}$ & $\begin{array}{l}(7) \\
3000 \\
1600\end{array}$ & $\begin{array}{l}(14) \\
6200 \\
3200\end{array}$ & & \\
\hline 5 & 68 & $M$ & C.B. & 3 b.d. & 7 days & $\begin{array}{ll} & (1) \\
W B C & 3800 \\
N & 2500\end{array}$ & $\begin{array}{l}(7) \\
3600 \\
1900\end{array}$ & $\begin{array}{l}(21) \\
4600 \\
2200\end{array}$ & & \\
\hline 6 & 64 & $\mathrm{~F}$ & C.B. & 2 b.d. & 7 days & $\begin{array}{ll} & (1) \\
\text { WBC } & 4700 \\
\mathbf{N} & 3000 \\
\end{array}$ & $\begin{array}{l}(7) \\
4000 \\
2400 \\
\end{array}$ & & & \\
\hline 7 & 62 & $M$ & C.B. & 2 b.d. & $\begin{array}{l}28 \text { days } \\
10 \text { days off } \\
5 \text { days }\end{array}$ & $\begin{array}{ll} & (1) \\
\text { WBC } & 9800 \\
N & 7000\end{array}$ & $\begin{array}{l}(28) \\
7700 \\
2700\end{array}$ & $\begin{array}{l}(43) \\
5600 \\
2600\end{array}$ & $\begin{array}{r}(50) \\
4400 \\
1700\end{array}$ & $\begin{array}{r}(57) \\
11,000 \\
8800\end{array}$ \\
\hline 8 & 51 & $M$ & C.B. & 3 b.d. & 7 days* & $\begin{array}{l}\text { (1) } \\
\text { WBC 6400 } \\
\text { N "normal" }\end{array}$ & $\begin{array}{l}(7) \\
4600 \\
2200\end{array}$ & & & \\
\hline
\end{tabular}

* 14 days treatment with 2 tabs. twice daily completed 2 weeks previously.

$\mathrm{A}=$ asthma $\quad \mathrm{B}=$ bronchitis $\quad \mathrm{C} . \mathrm{B}=$ chronic bronchitis. $\quad \mathrm{WBC}=$ total white count. $\mathrm{N}=$ neutrophils methoxazole 2.4 g., usually for 7 or 14 days. White cells were counted on the first day of treatment and again on the last day. The lower limit of normal for the white cell count was taken as 4,000 per cu. $\mathrm{mm}$. and for neutrophils 2,500 per cu. $\mathrm{mm}^{\mathrm{s}}$

Out of the 32 patients there were eight whose neutrophil counts were below normal at the end of treatment ; seven of these also had an abnormally low total white cell count. These abnormalities seemed to be significant in four patients $(1-4$; Table), but the other four abnormal counts could have been due to experimental error. Twenty-four of the remaining 28 total white counts fell after treatment, though not dropping below normal levels ; initially eight of these had shown a leucocytosis and 16 had been normal. The affected group showved no important difference in age, sex, dosage, or length of treatment. Patients 7 and 8 had had a previous course and patient 4 was given a subsequent course without adverse effect on the white cells on these occasions.

The return of the white cell count to normal was prompt in two patients but in-
1.6 g., or trimethoprim $480 \mathrm{mg}$. with sulpha- complete in one patient fourteen days after treatment finished, though ultimately complete in all. It must be stressed that there was no clinical evidence of illness attributable to the neutropenia, and that there was no evidence of its having affected the patients adversely.

I wish to thank Dr. M. Caplin, of the London Chest Hospital, who initiated the study and Dr. I. Lenox-Smith, of Roche Products Limited, who supplied the Bactrim.

-I am, etc.,

\section{O. R. MCCARTHY} London Chest Hospital.
London E.2.

\section{REFERENCES}

Darrell, J. H., Garrod, L., P., and Waterworth, 202. M., fournal of Clinical Pathology, 1968, 21, Drew, C. D. M., Hughes, D. T. D., Fowle, A. S. E., and Cassell, M. A., in Proceedings of the Sth International Congress of Chemotherapy, edited by $\mathrm{K}$. $\mathrm{H}$. Spitzy and $\mathrm{H}$. Medical Academy. Medical Academy
Reeves, D. S., Faiers, M. L., Pursell, R. F., and Brumfitt, W., British Medical fournal, 19691,541

- Grüneberg, R. N., and Kolbe, R., British Medical fournal, $1969,1,545$.

Daoie, J. V., and Lewis, S. M., Practical
Haematology, 1968, 4th ed. London, Churchill. was a typical generalized erythrodermia with extensive superficial desquamation, and in addition there were many excoriated nodular lesions. The nly other abnormal physical finding was a mild generalized lymphadenopathy. Sigmoidoscopy revealed mild mucosal oedema in the distal $10 \mathrm{~cm}$. of the bowel with no ulceration or contact bleeding ; mucosal scrapings were taken and immediately examined microscopically. They showed haematophagous Entamoeba histolytica trophozoites. His amoebiasis was treated with metronidazole. No underlying cause was found for his erythrodermia, which was treated symptomatically with some difficulty.

There can be little doubt that this patient's recent diarrhoeal illness was acute amoebic dysentery. Although he had no bowel symptoms when first seen by us, the finding of haematophagous trophozoites indicates that the amoebiasis was still in an invasive phase. We presume that prior to the steroid therapy this patient was an asymptomatic amoebic cyst-passer. It should be pointed out that a cyst-passer who develops diarrhoea for any reason, including that following the administration of a purgative may sometimes show small trophozoites in the stool. These are never haematophagous and are referred to as the minuta forms of $E$. histolytica. However, this does not apply to our patient.

We are grateful to Professor A. W. Woodruff and $\mathrm{Dr}, \mathrm{H}, \mathrm{A}, \mathrm{K}$. Rowland for permission to publish this case report.

-We are, etc.,

S. R. KANANI. R. KNIGHT.

Medical Unit, Hospital for Tropical Diseases
London N,W.1.

\section{Hospital Planning}

SIR,-Professor E. D. Acheson's informative article (21 June, p. 750) on Southampton Medical School is illustrated by a photograph of the plan of a new Southampton General Hospital complex. It contains ward blocks for 1,300 patients, together with the ancillary services and teaching facilities. It contains four nine-storey residential blocks and three three-storey residential blocks. It contains the administrative offices, the laundry, the nurses' home, etc. It contains the outpatient services. It will certainly contain a very large number of people, many of whom, patients and others, will go to and from the hospital each day.

It contains no provision whatever for car parking.

The planning of this complex has occupied the time of a great number of people for some time past, and will continue to do so for some time to come. Integrated planning has been done in great detail, down to the size and shape of the smallest rooms. Most of those concerned have at one time or another spoken of the need for very large car-parking facilities, but this is always immediately met by the statement that the Ministry will make no provision for this.

The fundamental basic object in building this complex is to provide a meeting-place for patients, doctors, nurses, teachers, students, administrators, and lay workers. They will be coming and going at all times of the day and night, seven days a week. No matter what public transport services may be available, very many will require Ceylon for 30 years, returned to Britain about six years ago, since when he has visited Ceylon ance for a five-week period in 1967. He was treated for "dysentery" during his first voyage home. In November 1967 he developed a mild pruritic dermatosis on his legs and forearms, Dapsone therapy was then developed oedema of the face, cervical lymphlesions.

When first seen by us on 14 April he complained of intense pruritus, but the diarrhoea had completely subsided. On examination there which gradually became worse and generalized. who diagnosed dermatitis herpetiformis and he started treatment with dapsone and oral antstarting steroid therapy he developed diarrhoea with fresh blood and mucus; he was passing seven stools each day. These symptoms sisted until one week after the steroids were 